\title{
PENGARUH KUALITAS PELAYANAN TERHADAP KEPUASAN DAN LOYALITAS NASABAH BANCO NACIONAL COMERCIO TIMOR LESTE (BNCTL)
}

\author{
Artur Avila de Jesus Boavida \\ Fakultas Ekonomi Universitas Udayana (UNUD), Bali Indonesia \\ e-mail: arturaviladejesusboavida@yahoo.com
}

\begin{abstract}
ABSTRAK
Tujuan penelitian ini untuk menjelaskan pengaruh kualitas pelayanan terhadap kepuasan dan loyalitas nasabah. Hasil uji validitas instrumen variabel bebas dan variable terikat memiliki koefisien korelasi positif dengan nilai di atas 0.30. Hasil konformatori variabel kualitas pelayanan, kepuasan dan loyalitas nasabah diketahui bahwa semua indikator mempunyai factor loading diatas 0.60. Berdasarkan Hasil dari koefisien determinan $45.48 \%$ mampu menjelaskan model ini dan sisanya 54.51 dipengaruhi oleh faktor lain. Hasil pengujian hipotesis kualitas pelayanan berpengaruh signifikan terhadap Kepuasan. Kualitas pelayanan berpengaruh signifikan terhadap loyalitas nasabah dan Kepuasan berpengaruh signifikan terhadap loyalitas nasabah. Berdasarkan pembahasan hasil penelitian maka perlu adanya saran yang diberikan untuk perbaikan pada dimensi kualitas pelayanan khususnya bukti fisik yaitu fasilitas sebagai sarana untuk melakukan transaksi keuangan serta dimensi daya tangap dalam penyampaian informasi yang jelas agar dapat memenuhi harapan sehingga nasabah tetap loyal dalam pengunaan produk maupun tetap melakukan transaksi keuangan.
\end{abstract}

Kata kunci: Kualitas pelayanan, kepuasan dan Loyalitas nasabah

\begin{abstract}
The purpose of this research to explain the influence of the quality of service for customer satisfaction and loyalty. Test the validity of an instrument of free and variable variable bound having a correlation coefficient with a value above 0.30 positive .The results of konformatori variable quality of services, satisfaction and loyalty of customers have known that all indicators of loading up 0.60 factor. Based on the results of the coefficients determinan $45.48 \%$ capable of being explained this model and the rest 54.51 influenced by other factors. The results of the testing of hypotheses service quality influential significantly to satisfaction .The quality of service influential significantly to customer loyalty and satisfaction influential significantly to customer loyalty. Based on the discussion of the results of research and the need of advice given to improvements in the dimensions of quality of services especially physical evidence that is the facility as a means to do financial transaction as well as the dimensions of resources in the delivery of tangap clear information to meet the expectations so that customers remain loyal in using the product and is still conducting financial transactions .
\end{abstract}

Keyword: Quality Of Service, Satisfaction And Loyalty Customers 


\section{Latar belakang}

Negara Republik Demokrasi Timor Lesta terdapat lima jenis institusi keuangan yang terdiri dari bank central dan bank komercial yaitu Bank Nasional Comercio Timor Leste, Bank ANZ, Bank Mandiri dan Bank BNU. Bank central didesain secara jelas menyangkut sistem keuangan dan peranan sangat fundamental untuk menjembatani pembangunan di sektor ekonomi dan sosial.

Persaingan dunia usaha yang semakin kompetitif, para pelaku perusahaan umumnya bergerak di bidang industri, perdagangan maupun jasa, khususnya pada perusahaan perbankan menciptakan dan mempertahankan nasabah dan mengekspansi bisnis ke tingkat daerah. Pertumbuahan ekonomi tidak terlepas dari peran sektor perbankan dan pelaku ekonomi di lembaga swasta maupun pemerintah yang bergerak dibidang jasa keuangan yang memiliki peranan penting dalam kegiatan perekonomian suatu Negara.

Banco Nacional Comercio Timor Leste awalnya hanya memberi pelayanan kepada masyarakat kecil yang membutuhkan dana untuk merealisasikan aktivitas usaha bisnis kecil dan simpan pinjam dengan bunga relatif kecil. Institusi keuangan dikelola oleh pemerintah dengan prinsip sebagai lembaga intermediasi yang menghimpun dana dari masyarakat dan menyalurkan kepada masyarakat yang membutuhkan. Bank keuangan dapat memperoleh nasabah semakin banyak dari tingkat daerah sampai tingkat nasional meliputi masyarakat biasa yang memerlukan dana.

Lembaga perbankan mengalami persaingan yang semakin tajam yang bergerak di bidang jasa, Kondisi ini membuat pihak perbankan dituntut untuk berpikir keras 
agar dapat menghadapi persaingan tersebut dengan selalu memberikan terobosan baru dalam memberikan pelayanan pada para nasabah. Bukti fisik (tangible), keandalan, daya tanggap (reliability), jaminan (responsiveness), dan empati (empathy), merupakan faktor dimensi kualitas jasa. Keberhasilan dari pemberian kualitas pelayanan ditunjukkan para nasabah secara prima dan unggul untuk memenuhi harapan dengan adanya rasa puas dari para nasabah.

Kegiatan transaksi keuangan sehari - hari yang dilakukan oleh karyawan Banco Nacional Timor Leste dengan nasabah ditinjau dari segi dimensi belum menunjukkan pelayanan yang kondusif bagi nasabah. Hal ini dilihat dari dimensi fisik dimana keadaan fasilitas kurang memadai untuk digunakan seperti toilet dan tempat parkir mobil dan motor, dan tingkat keandalan dalam memberikan informasi serta menyelesaikan masalah kurang mampu sehingga melibatkan struktural untuk menanganinya. Akibat dari pelayanan yang diberikan sangat terbatas dan standar namun nasabah tidak mengalihkan perhatian kepada Bank lain karena bank tersebut memberikan kemudaan untuk memgakses kredit dan pula masih sedikit bank nasional yang beroperasi.

Kepuasan nasabah Banco Nacional Comercio Timor Leste dapat dilihat secara jelas dalam tranksasi keuangan. Apabila nasabah merasa puas maka kinerja perusahaan dapat memenuhi harapan yang diinginkan. Namun mayoritas nasabah merasa harapanya tidak terpenuhi dilihat dari dimensi fisik dan empati akibat dari sistem standar operasional prosedur yang diimplementasikan dalam transaksi keuangan dimana nasabah saat menerima gaji bulanan baik nasabah yang statusnya pegawai negri sipil maupun nasabah mendapat subsidi dari pemerintah 
yakni para veteran, usia lanjut dan anak-anak yang cacat, diwajibkan menunggu dan antrian berkebanjangan sehingga mengaibaikan aktivitas lain untuk menerima gaji dan subsidi.

Kelanjungan hidup perusahaan berarti meningkatkan kinerja keuangan dan mempertahankan dimensi sehingga nasabah tetap loyal. Produsen selalu memperhatikan konsumen melakukan tranksaksi pembelian barang dan jasa yang tercermin dari suatu kebiasaan . kesetiaan adalah bagian dari loyalitas konsumen untuk tetap melalukan aktivitas tranksaksi keuangan yang berulang kali di Banco Nacional Comercio Timor Leste dan meyebarkan informasi kepada nasabah lain. Berdasarkan Latar belakang yang dipaparkan maka tujuan penelitian untuk menjelaskan pengaruh Kualitas pelayanan terhadap kepuasan dan loyalitas Nasabah di Banco Nacional Comercio Timor Leste.

\section{KAJIAN PUSTAKA}

\section{Kualitas Pelayanan}

Tjiptono (2000) dalam Purnomo mengungkapkan bahwa tidak ada definisi mengenai kualitas yang dapat diterima semua orang. Namun demikian ada elemen yang sama dalam berbagai definisi yang ada diantaranya adalah : 1) Kualitas berkaitan dengan memenuhi atau melebihi harapan konsumen, 2) Kualitas berlaku untuk jasa manusia, proses dan lingkungan, 3) Kualitas adalah kondisi yang selalu beruba. Menurut Aga (2007) Kualitas pelayanan dikatakan baik apabila dalam fungsinya mampu memberikan kemudahan dalam membuka rekening dari bank tersebut, persyaratan yang fleksibel dalam permohonan kredit, cepat dan tepat waktu dalam pelayanan, karyawan yang ramah dan sopan, kemampuan dan 
kompetensi karyawan dalam mengatasi keluhan dan masalah, perhatian karyawan terhadap nasabah serta fasilitas yang lengkap dan kinerja karyawan yang baik. Zeithmal, Bitner and Gremler (2013) Kualitas pelayanan merupakan sebuah elemen penting dari tanggapan pelanggan seperti kasus dalam peyanan murni, misalnya pelayanan kesehatan, pelayanan keuangan, dan pendidikan. Kualitas pelayanan akan menjadi elemen yang dominan dari penilaian pelanggan, dimana pelangan atau jasa yang ditawarkan dapat kombinasi dengan produk fisik, kualitas pelayanan sangat penting dalam menentukan kepuasan pelanggan. Penelitian oleh Parasuraman et al., (1988) menyatakan bahwa kualitas pelayanan secara umum dapat dibentuk oleh lima dimensi yaitu:(1) Keterwujudan (tangible), merupakan dimensi pelayanan yang menitik beratkan pada elemen-elemen yang mewakili pelayanan secara fisik (2) Kehandalan (reliability), merupakan kemampuan untuk memberikan jasa sebagaimana yang dijanjikan secara akurat (3) Daya Tangkap (responsiveness), yaitu dimensi kualitas pelayanan pada kemampuan untuk menghargai kepercayaan dan kerahasiaan (4) Jaminan (assurance), merupakan Dimensi ini menitikberatkan pada perilaku personel jasa untuk perhatian terhadap pelanggan (5) Empati (empathy) Merupakan menekankan pelayanan pelanggan sebagai seorang individu. Pengaruh kualitas pelayanan terhadap kepuasan nasabah yang menyatakan bahwa dari lima faktor (Reability, Responsiveness, Empathy, Assurance, dan Tangibility) mempengaruhi kepuasan nasabah yaitu Reability, Responsiveness, Empathy, dan Tangibility. (Mosahab et al., 2010)

\section{Kepuasan Nasabah}


Menurut Kasmir (2010) menyatakan bahwa apabila nasabah puas dengan pelayanan yang diberikan, maka nasabah loyal kepada bank dan kepuasan nasabah lama akan menular kepada nasabah baru sehingga mampu meningkatkan jumlah nasabah. Keller (2009) menyatakan bahwa jika kinerja gagal memenuhi ekspektasi pelanggan tidak akan puas. Jika kinerja sesuai dengan ekspektasi pelanggan akan puas. Kepuasan pelanggan merupakan respons pelanggan terhadap ketidaksesuaian tingkat kepentingan sebelumnya dan kinerja aktual yang dirasakannya setelah pemakaian (Rangkuti, 2002). Kepuasan adalah tingkat perasaan setelah membandingkan kinerja atau hasil yang dirasakan dengan harapannya (Sumarwan, 2003). Irawan (2002) menyatakan bahwa service quality sangat bergantung pada tiga hal yaitu sistem, teknologi dan manusia. Faktor manusia ini memegang kontribusi sekitar 70\% agar pelayanan memiliki kualitas dan memberikan kepuasan kepada pelanggan.

\section{Loyalitas Nasabah}

Menurut Cadogan ( 2000) Loyalitas adalah sikap dari nasabah membuat komitmen dalam menentukan pilihannya untuk tetap menggunakan produk atau jasa dan melakukan pembelian ulang pada perusahaan tersebut. Menurut Kotler et al., (2002) terdapat enam alasan perusahaan mendapatkan loyalitas pelanggannya. Pertama: pelanggan yang sudah ada lebih prospektif, artinya pelanggan setia memberi keuntungan besar pada perusahaan. Kedua: biaya mendapatkan pelanggan baru jauh lebih besar dibanding menjaga dan mempertahankan pelanggan yang sudah ada. Ketiga: pelanggan yang sudah percaya pada perusahaan dalam suatu urusan cenderung akan dalam urusan lainnya. Keempat: biaya operasi perusahaan 
menjadi efisien jika memiliki banyak pelanggan setia. Kelima: mengurangi biaya psikologis dan sosial disebabkan pelanggan lama telah banyak pengalaman positif dengan perusahaan. Keenam: pelanggan setia selalu membela untuk menarik dan memberi saran kepada orang lain untuk menjadi pelanggan. Menurut Zulkarnain (2012) menjelaskan, bahwa mendapatkan pelanggan yang puas dan loyal merupakan peluang besar bagi perusahaan untuk memperluas jaringan pemasaran, walaupun disatu sisi mempertahankan pelanggan jauh lebih menguntungkan dibanding pergantian pelanggan baru karena biayanya jauh lebih besar. Menurut Wright (2005), loyalitas adalah keputusan pelanggan untuk secara sukarela terus berlangganan dengan perusahaan tertentu dalam jangka waktu yang lama. loyalitas merupakan besarnya konsumsi dan pembelian oleh seorang pelanggan terhadap suatu perusahaan dan berhasil menemukan bahwa kualitas keterhubungan yang terdiri dari kepuasan, kepercayaan dan komitmen Wulf dkk, (2011)

\section{KERANGKA BERPIKIR, KONSEPTUAL DAN HIPOTESIS}

\section{Kerangka Berpikir dan Konseptual}

Menurut Parasuraman et.al (1988) yang dikutip oleh Lupiyoadi (2001) bahwa service quality atau kualitas layanan dapat didefinisikan sebagai seberapa jauh perbedaan antara kenyataan dan harapan para nasabah atas layanan yang mereka terima atau peroleh". Kelima dimensi tersebut seperti antara lain: (a) Bukti fisik (Tangibles) yaitu penampilan fasilitas fisik, peralatan, personil, dan media komunikasi. (b) Keandalan (Reliability) yaitu kemampuan untuk melaksanakan jasa yang dijanjikan dengan tepat dan terpercaya. (c) Daya tanggap 
(Responsiveness) yaitu kemauan untuk membantu pelanggan dan memberikan jasa dengan cepat. (d) Jaminan (Assurance) yaitu pengetahuan dan kesopanan karyawan dan kemampuan mereka untuk menimbulkan kepercayaan dan keyakinan. (e) Perhatian (Empathy) yaitu syarat untuk peduli memberikan perhatian bagi pelanggan. Menurut Zulganef (2002) dan Ramadania (2002), indikator dari Kepuasan nasabah adalah: (1) Kepuasan terhadap sistem perusahaan atau perbankan. (2) Kepuasan terhadap kualitas layanan perusahaan atau perbankan. (3) Kepuasan keseluruhan terhadap kinerja perusahaan. Menurut Iacobu et al.,( 2002), Pelanggan adalah orang yang biasa membeli pada suatu perusahaan secara tetap. Kebiasaan ini dibangun melalui pembelian dan interaksi tanpa adanya jalinan hubungan yang kuat. pembeli mendefinisikan loyalitas sebagai besarnya konsumsi dan frekuensi pembelian yang dilakukan oleh seorang konsumen terhadap suatu perusahaan. Pelanggan yang setia menurut Griffin (1995), pelanggan yang setia adalah pelanggan yang membeli produk dan jasa secara berulang-ulang pada perusahaan yang sama dan memberitahukan kepada orang lain kepuasan-kepuasan yang didapat dari perusahaan. Loyalitas merupakan tujuan relationship marketing. Untuk mempertahankan loyalitas, tidak hanya dapat menyandarkan pada kepuasan yang dirasakan pelanggan, tetapi lebih dari kepercayaan dan komitmen merupakan kunci dalam membangun loyalitas.

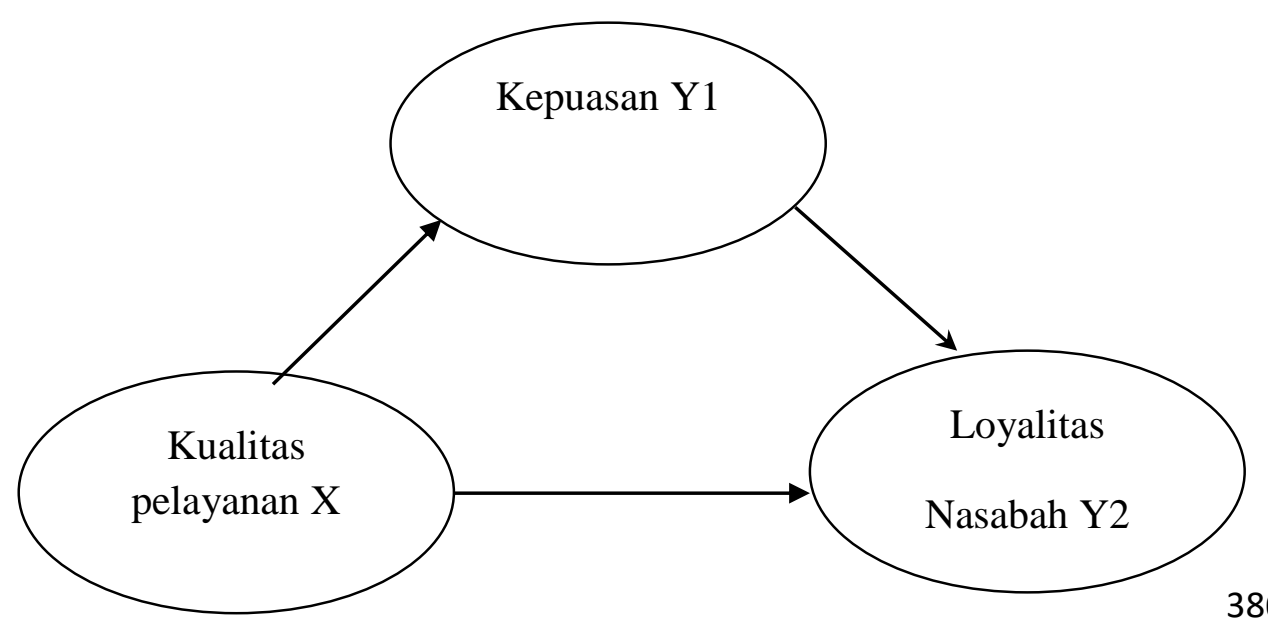




\section{Gambar 1 Konseptual Pemikiran}

\section{Hipotesis}

\section{Pengaruh Kualitas Layanan Terhadap Kepuasan}

Menurut Hidayat et al., (2015) Berdasarkan hasil pengujian secara statistik secara langsung menunjukkan bahwa PT Bank BTN Cabang Tuban melalui pelayanan yang baik positif secara langsung terhadap variabel kepuasan pelanggan sebesar $0,729(72,9 \%)$ dengan nilai $p$-value 0,00 , sedangkan sisanya sebesar $27,1 \%$ . Pengaruh antara kualitas layanan terhadap loyalitas pelanggan secara langsung sebesar 0,004 dengan nilai $p$-value 0,971 pengaruh tidak langsung sebesar 0,667 dan pengaruh total sebesar 0,654. Pengaruh yang dihasilkan tersebut tidak signifikan sehingga hipotesis ditolak. Sedangkan variabel kepuasan pelanggan memiliki pengaruh secara signifikan dan kuat dengan vaariabel loyalitas pelanggan yang dari nilai pengaruh langsung sebesar 0,910. Menurut (Windarti et al., 2012) variabel tangible, reliability, responsiveness, assurance, dan emphaty yang merupakan variabel independen dengan kepuasan nasabah yang merupakan variabel dependen adalah kuat dan berpengaruh secara bersama-sama (simultan) terhadap kepuasan nasabah. Uji simultan (uji F) menunjukkan bahwa P value 0,000 
$<0.05$ dan Fhitung lebih besar dari $\mathrm{F}$ tabel $(6,441>2,35)$ yang artinya signifikan. Berdasarkan pada kerangka berpikir dan konseptual serta rujukan Hipotesis penelitian terdahulu yang telah dipaparkan diatas maka peneliti memberikan jawaban sementara dimana menunjukan hipotesis ini adalah:

H1: Kualitas Pelayanan berpengaruh positif dan signifikan terhadap Kepuasan Nasabah

\section{Pengaruh Kualitas Layanan Terhadap Loyalitas Nasabah}

Kualitas pelayanan memiliki pengaruh positif dan signifikan terhadap loyalitas pelanggan pada $\beta=5$ persen $(p=0,007)$ dengan koefisien 0,488 . Hal ini berarti semakin baik kualitas pelayanan yang diberikan Tegal Sari Accommodation maka loyalitas pelanggan akan meningkat. Studi ini yang dilakukan oleh Akbar dan Pavez (2009). kepuasan pelanggan memiliki pengaruh positif dan signifikan terhadap loyalitas pelanggan, pada $\beta=5$ persen $(p=0,011)$ dengan koefisien 0,461 . Berdasarkan model loyalitas pelanggan yang dikemukakan oleh (Uncles, et al. 2003) dalam Tjiptono (2007) loyalitas yang terjadi mengarah pada terjalinnya relasi dengan merek, dimana ada komitmen sikap terhadap suatu merek, baru bisa terbentuk loyalitas sejati. Berdasarkan pada kerangka berpikir dan konseptual serta rujukan Hipotesis penelitian terdahulu yang telah dipaparkan diatas maka peneliti memberikan jawaban sementara dimana menunjukan hipotesis ini adalah:

H2: Kualitas Pelayanan berpengaruh positif dan signifikan terhadap Loyalitas Nasabah

\section{Pengaruh kepuasan Terhadap Loyalitas Nasabah}


Menurut (Jawas Dkk., 2003), menemukakan hasil output bahwa kualitas pelayanan memiliki pengaruh positif dan signifikan terhadap kepuasan pelanggan pada $\beta=5 \%(\mathrm{p}=0,000)$ dengan koefisien 0,898 . hasil penelitian sebelumnya. Hasil penelitian Anggraeni hasil analisis pengaruh Kualitas Pelayanan terhadap Kepuasan Nasabah dengan thitung $(11,254)$ dan lebih besar dari t tabel $(1,960)$ atau tingkat signifikansi $(0,000)$ lebih kecil dari alpha 5\% $(0,05)$ menyatakan bahwa terdapat pengaruh yang nyata antara Kualitas Pelayanan terhadap Kepuasan Nasabah. Hasil analisis path menunjukkan nilai koefisien sebesar 0,828 dan bertanda positif signifikan menyatakan pengaruh Kualitas Pelayanan terhadap Kepuasan Nasabah adalah semakin tinggi. Menurut Day (dalam Tjiptono 2004) hasil pengujian hipotesis menunjukkan bahwa nilai t hitung untuk kepuasan nasabah adalah 8,619 dengan signifikansinya sebesar 0,028 , sedangkan pada taraf signifikansi sebesar 0,025 dengan df sebesar $=92$ diperoleh nilai t tabel sebesar 1,986 sehingga nilai $\mathrm{t}$ hitung $=8,619>$ nilai $\mathrm{t}$ tabel $=1,986$. Dengan demikian menunjukkan bahwa terdapat pengaruh signifikan antara kepuasan nasabah terhadap loyalitas nasabah. Bloemer et al. (1998) dan Ruyter (1997), menjelaskan bahwa kepuasan sering kali dipandang sebagai dasar munculnya loyalitas. Kepuasan ternyata memiliki pengaruh positif dan signifikan terhadap loyalitas. Penelitian yang dilakukan. Berdasarkan pada kerangka berpikir dan konseptual serta rujukan Hipotesis penelitian terdahulu yang telah dipaparkan diatas maka dapatlah disusun hipotesis sebagai berikut :

H3: Kepuasan berpengaruh positif dan signifikan terhadap loyalitas nasabah 


\section{METODE PENELITIAN}

\section{Jenis dan Ruang Lingkup Penelitian}

Penelitian dilakukan pada pelanggan Bank Nacional Comercio Timor Leste (BNCTL) yang berada di Jl. Fumentu Mandarin, Dili. Pendekatan yang digunakan dalam penelitian adalah dengan cara survei untuk mendapat data Sugiyono (2008).

\section{Variabel Penelitian}

Penelitian diperjelas dengan variabel bebas (X) dan Variabel Terikat (Y). Variabel bebas yaitu kualitas Pelayanan yang diberi notasi X dan Variabel terikat yaitu Kepuasan yang diberi Notasi Y1 dan Loyalitas Nasabah yang diberi notasi Y2.

\section{Identifikasi Variabel,}

Variabel laten dalam penelitian ini adalah Kualitas Layanan, Kepuasan dan Loyalitas Nasabah sedangkan variabel manifes yaitu indikator dari setiap variabel antara lain : 1)Variabel Kualitas Layanan (X1) dengan mengunakan lima dimensi dan indikator (Parasurman et.al. 1988 ) yaitu : (1) Realiabilaity X1.1 (2) Responsiviness X1.2. (3) Assurance X1.3. (4) Empathy X1.4. (5) Tangibles X1.5. 2) Kepuasan Y1 dengan mengunakan tujuh indikator dari salah satu pengukuran kepuasan pelanggan Gerson (2001) yang dilihat dari yaitu : (1) Puas akan kualitas layanan Y1.1(2) Puas dengan layanan ideal Y1.2 (3) Puas dengan Fasilitas yang tersedia Y1. (4) Senang meminjam dan menabung Y1.4.(5) Puas dengan sistem Transaksi Y1.5. (6) Manfaat dari pelayanan yang diterima Y1.6.(7) Keputusan 
menabung yang tepat (Y1.7). 3) Loyalitas Nasabah Y2 dengan mengunakan enam indikator menurut (Hasan, 2009) sebagai berikut : (1) Tetap menjadi nasabah Y2.1. (2) Merekomendasikan kepada orang lain Y2.2. (3) Yakin untuk menjadi nasabah tetap Y2.3. (4) Loyal apabila prlengkapan dan fasilitas sangat cangih dan modern Y2.4.(5) Loyal apabila saran dan masukan dari nasabah menjadi bahan pertimbangan kputusan Y2.5. (6) Bank Mempertahankan demnsi layanan Y2.6

\section{Definisi Operasional,}

Untuk memberikan informasi yang jelas dan akurat kepada responden untuk memperoleh data dilapangan, Maka perlu adanya definisi operasional pada variabel - veriabel serta demensi dan indikator yang digunakan oleh peneliti. Definisi operasional yang di digunakan dalam penelitian sebagai berikut : 1) Variabel Kualitas Pelayanan adalah tingkat keunggulan untuk memenuhi keinginan nasabah. 2) Kepuasan Nasabah adalah tingkat di mana pelanggan atau nasbah menyakini bahwa harapannya terpenuhi atau terlampaui oleh manfaat yang diterima. Dimana indikatornya. 3) Loyalitas Nasabah Loyalitas konsumen berarti suatu kondisi dimana konsumen mempunyai sikap positif terhadap sebuah merek dan bermaksud meneruskan pembeliannya di masa mendatang.

\section{Metode Pengumpulan Data}

Data Kuantitatif dalam penelitian mengunakan bentuk deskriptif dan survei yaitu suatu metode pengumpulan data memberikan gambaran yang cukup jelas mengenai obyek yang diteliti berdasarkan penelitian dan diinterpretasikan dalam bentuk angka atau nomerik. Data Kualitatif . Data kualitatif dalam penelitian ini meliputi Struktur Organisasi Banco Nacional Comercio Timor Leste dan kuesioner 
responden. Dua sumber data yaitu Data primer. Data primer adalah data yang dikumpulkan dan disusun oleh peneliti sendiri yang diperoleh melalui kuesioner,wawancara, atau observasi. Data sekunder adalah data yang disajikan atau disiapkan dalam bentuk jadi oleh suatu perusahaan atau lembaga pemerintah yang berkaitan dangan judul penelitian.

Populasi adalah seluruh nasabah yang melakukan transaksi keuangan di Banco Nacional Comercio Timor .Sampel adalah bagian dari jumlah dan karakterisik yang dimiliki oleh populasi tersebut (Sugiyono, 2008). Sampel dalam penelitian ini adalah sebanyak 120 nasabah dan Teknik pengambilan sampel yang akan menggunakan metode purposive sampling, criteria menjadi nasabah simpanan Bank Nasional Komerial Timor Leste selama 1 tahun yang bisa dianggap sebagai nasabah (Bloemer et al., 1998).

Skala Pengukuran Instrumen yang digunakan dalam penelitian ini adalah kuesioner dengan jawaban menggunakan skala interval "itemized rating scale" (Sekaran, 29 ), yang dibagi dalam empat jenjang yaitu : ( 1) Jawaban Sangat Setuju dengan skor 5. (2)Jawaban Setuju dengan skor 4. (3) Jawaban Netral dengan skor 3. (4) Jawaban Tidak Setuju dengan skor 2.(5) Jawaban Sangat Tidak Setuju dengan skor 1 .

Uji validitas Pengujian valid tidaknya daftar pertanyaan yang diajukan adalah dengan menggunakan analisis faktor. Tinggi rendahnya validitas suatu angket dengan melihat korelasi item-item pertanyaan dengan kontruk yang diukurnya. peneliti menetapkan nilai factor loading yang signifikan adalah lebih dari $=0,50$. 
Uji reliabilitas menunjukkan alat pengukuran dapat dipercaya sejauh mana hasil pengukuran tetap konsisten bila dilakukan pengukuran dua kali atau lebih terhadap gejala yang sama, (Sekaran, 2000). Indikator pengukuran reliabilitas dengan kriteria sebagai berikut : Jika alpha atau $\mathrm{r}$ hitung Kurang dari 0,6 = Reliabilitas kurang baik

\section{Cara Pengumpulan Data}

Penelitian lapangan adalah penelitian yang dimaksudkan untuk memperoleh data primer yaitu : 1) Kuesioner yaitu data dengan membuat daftar pertanyaan yang berkaitan dengan objek yang akan diteliti. 2)Wawancara yaitu suatu teknik pengumpulan data dengan cara tanya jawab dengan dengan obyek yang diteliti. 3) Observasi yaitu suatu teknik pengumpulan data dengan mengamati secara langsung objek lapangan penelitian.

\section{Metode Pengujian Hipotesis}

\section{Uji Asumsi Klasik.}

Uji Auto Korelasi Autokorelasi adalah hubungan korelasi dari masing-masing variabel waktu sekarang akan sama keadaanya pada masa yang akan datang. Pengujian yang digunakan untuk mengetahui autokorelasi adalah uji Durbin Watson.

Uji Multikorlasi yaitu hubungan linier yang sempurna atau eksak (perfect or exact) diantara variabel-variabel bebas dalam model regresi. Dari hasil perhitungan menunjukkan bahwa nilai VIF Keragaman produk dan kualitas pelayanan memiliki VIF masing-masing nilai dibawah dari 10, maka dapat dikatakan tidak terjadi multikolinearitas antara variabel bebas. 
Uji Heterokedastisitas.Titik-titik tersebut menyebar baik diatas maupun dibawah angka 0 pada sumbu y.

Uji normalitas bertujuan untuk menguji apakah dalam model regresiverbal dependen, variabel independen, atau keduanya mempunyai distribusi normal atau tidak. Model regresi baik adalah distribusi data normal atau mendekati normal.

Regresi Linear Berganda dimaksudkan untuk mengetahui keeratan, pengaruh yang ada di antara kedua variabel. Metode regresi linier ini juga dapat digunakan untuk peramal dengan menggunakan data berkala (timeseries).

Rumus Linear Berganda

$\mathrm{Y}=\mathrm{a}+\mathrm{b} 1 \times 1+\mathrm{b} 2 \times 2+\mathrm{b} 3 \times 3$

Keterangan :

$\mathrm{Y}^{1}=$ Subyek dalam variabel independen yang diprediksikan

$\mathrm{a}=$ banyak jumlah $\mathrm{Y}$ bila $\mathrm{X}=0$ (konstan)

$\mathrm{b}=$ Angka arah koefisien regresi yang menunjukkan angka peningkatan atapun penurunan variabel independen. Bila $\mathrm{b}(+)$ positif, maka naik, dan bila $\mathrm{b}(-)$ negatif maka terjadi penurunan.

$\mathrm{X}=$ Subyek pada variabel independen yang mempunyai nilai tertentu

Uji $\mathrm{T}$ - tes ini digunakan untuk mengetahui pengaruh dari masing - masing variabel independen terhadap variabel dependen. Jika nilai signifikan a $<0,05$ maka dapat dikatakan bahwa terdapat pengaruh yang signifikan antara variabel independen dengan variabel dependen secara individu. Sebaliknya jika nilai signifikan a > 0,05 maka tidak terdapat pengaruh yang signifikan (Santosa, 2000). Sedangkan untuk perhitungan nilai t adalah :

Keterangan :

$$
\mathrm{b}=\frac{\mathrm{beta}(\mathrm{b})}{\mathrm{Sb}(\mathrm{b})}
$$

Beta (b) : Kemiringan $\beta$

$\mathrm{Sb}(\mathrm{b}) \quad$ : Kesalahan baku $\beta$ 
Uji F - test Digunakan untuk mengetahui apakah ada pengaruh yang signifikan variabel independen secara bersama-sama terhadap variabel dependen. Apabila nilai signifikan $<0,05$ maka Ho ditolak dan Ha diterima yang berarti variabel independen secara bersama-sama berpengaruh signifikan terhadap variabel dependen, dan apabila nilai signifikan > 0,05 maka Ho diterima dan Ha ditolak yang berarti variabel independen secara bersama-sama tidak berpengaruh signifikan terhadap variabel dependen (Santosa, 2000). Sedangkan perhitungan niali F adalah

Keterangan

$$
\mathrm{F}_{\mathrm{reg}}=\frac{\mathrm{R}^{2}(\mathrm{~N}-\mathrm{m}-1)}{\mathrm{m}-\left(1-\mathrm{R}^{2}\right)}
$$

$\mathrm{F}_{\text {reg }}=$ harga $\mathrm{F}$ garis regresi

$\mathrm{N}=$ cacah kasus

$\mathrm{M}=$ cacah prediktor

$\mathrm{R}^{2}=$ koefisien korelasi antara kriterium dengan prediktor- prediktor $\mathrm{Uji}^{2}$ (Koefisien Determinan)

Uji koefisien determinan $\left(\mathrm{R}^{2}\right)$ yang besarnya antara 0 sampai 1 atau $0 \leq R^{2} \leq 1$. Jika $\mathrm{R}^{2}$ mendekati 1 , berarti bahwa variabel bebas berpengaruh terhadap variabel terkait sehingga model yang digunakan dapat dikatakan baik. (Supranto, 1994). Rumusan Koefisien Determinan $\left(\mathrm{R}^{2}\right)$, yaitu :

Keterangan

$$
R^{2}=\frac{1 \sum \mathrm{ei}^{2}}{2 a \sum y i^{2}}
$$

$\mathrm{R}^{2}=$ koefisien determinan

$\mathrm{ei}^{2}=$ nilai kuadrat regresi

$\mathrm{yi}^{2}=$ nilai kuadrat variabel residua

\section{HASIL PENELITIAN DAN PEMBAHASAN}

\section{Uji Validitas Data}


Uji validitas digunakan validitas kriteria, yaitu dihitung berdasarkan korelasi antara skor tiap butir dengan skor total indikator. Instrumen dinyatakan valid jika memiliki korelasi positif dan lebih besar 0,30. Berdasarkan hasil uji validitas instrumen terbukti bahwa instrumen penelitian ini sudah valid karena seluruh butir pertanyaan dalam instrumen untuk semua variabel memiliki koefisien korelasi positif dengan nilai koefisien korelasi di atas $0,30(r>0,30)$. Selengkapnya hasil uji validitas instrumen

\section{Uji Realiabilitas}

Berdasarkan Hasil uji reliabilitas instrumen menunjukkan variabel kualitas pelayanan dengan nilai Conbach Alpha sebesar 0.948. Instrumen variabel kepuasan juga dapat dipercaya karena menunjukan nilai koefisien cronbach alpaha sebesar 0.94. Instrumen dari variabel loyalitas dinyatakan reliabel karena nillai Alpha Cronbach sebesar 0.898. Hasil dari masing-masing instrumen variabel lebih besar dari 0.60 .

\section{Deskripsi Variabel Kualiatas Pelayanan (X),}

Hasil analisis deskriptif variabel Kualitas pelayanan (X) berupa proporsi jawaban responden pada alternatif jawaban untuk setiap butir pertanyaan pada tabel berikut.

Tabel 1.

Deskripsi Variabel Kualiatas Layanan (X) 


\begin{tabular}{|l|l|c|c|}
\hline Indikator & Keterangan & $\begin{array}{c}\text { Rata- } \\
\text { Rata }\end{array}$ & Ket \\
\hline X1.1 & Bukti fisik & 3.68 & Baik \\
\hline X1.2 & Keandalan & 3.85 & Baik \\
\hline X1.3 & Daya tanggap & 3.74 & Baik \\
\hline X 1.4 & Jaminan & 3.74 & Baik \\
\hline X 1.5 & Empati & 3.79 & Baik \\
\hline
\end{tabular}

Sumber: Data Analisis SPSS

Berdasarkan pada Tabel 1 diatas dapat diketahui bahwa kualitas pelayanan tergolong dipersepsikan baik oleh responden. Hal ini dilihat dari nilai skor rata-rata variabel kualitas Pelayanan sebesar 3,80 yang dikategorikan baik, maka itu, dimensi pelyana sangat penting untuk pertahankan.

\section{Deskripsi Variabel Kepuasan (Y1)}

Tabel 2 Deskripsi Variabel Kepuasan (Y1)

\begin{tabular}{|l|l|c|c|}
\hline Indikator & Keterangan & $\begin{array}{c}\text { Rata- } \\
\text { Rata }\end{array}$ & Ket \\
\hline Y1 & Kepuasan Nasabah & $\mathbf{3 . 6 4}$ & Baik \\
\hline Y1.1 & Puas akan kualitas pelayanan yang diberikan & 3.41 & $\begin{array}{l}\text { Cukup } \\
\text { baik }\end{array}$ \\
\hline Y 1.2 & $\begin{array}{l}\text { Persepsi pelayanan ideal dan memuaskan oleh } \\
\text { Karyawan }\end{array}$ & 3.58 & Baik \\
\hline Y1.3 & Puas dengan fasilitas yang disediakan & 3.48 & Baik \\
\hline Y1.4 & Senang menabung dan memijam uang & 3.86 & Baik \\
\hline Y1.5 & puas dengan sistem transaksi yang dijalankan & 3.54 & Baik \\
\hline Y1.6 & $\begin{array}{l}\text { Manfaat dari pelayanan yang diterima sangat } \\
\text { memuaskan }\end{array}$ & 3.75 & Baik \\
\hline Y1.7 & $\begin{array}{l}\text { Keputusan menabung merupakan keputusan yang } \\
\text { tepat dan baik. }\end{array}$ & 3.68 & Baik \\
\hline Y1.8 & Puas dengan hasil yang diberikan & 3.87 & Baik \\
\hline
\end{tabular}

Sumber: Data Analisis SPSS

Memperhatikan informasi pada Tabel 2 di atas dapat diketahui bahwa Kepuasan nasabah tergolong dipersepsikan baik oleh responden. Hal ini dilihat dari 
nilai skor rata-rata variabel kualitas pelayanan sebesar 3,64. Hasil tersebut menunjukan bahwa setiap variabel Kepuasan Nasabah dilihat dari indikator Y1.1 sapai dengan Y1.8 jawaban diatas nilai rata $(3,43-4,23)$ artinya pelayanan yang diberikan oleh karyawan banco nacional timor leste sesuai dengan kinerja dan harapan nasabah.

\section{Deskripsi Variabel Loyalitas Nasabah (Y2)}

Tabel 3 Deskripsi Variabel Loyalitas Nasabah (Y2)

\begin{tabular}{|l|l|c|c|}
\hline Indikator & Keterangn & $\begin{array}{c}\text { Rata- } \\
\text { Rata }\end{array}$ & Ket \\
\hline Y2 & Loyalitas Nasabah & $\mathbf{3 . 8 2}$ & Baik \\
\hline Y2.1 & $\begin{array}{l}\text { Tetap menjadi nasabah dan tidak berpindah ke bank } \\
\text { lain. }\end{array}$ & 3.91 & Baik \\
\hline Y2.3 & $\begin{array}{l}\text { Bersedia untuk merekomendasikan Kepada kepada } \\
\text { orang lain }\end{array}$ & 3.93 & Baik \\
\hline Y2.4 & $\begin{array}{l}\text { Yakin bahwa menjadi nasabah adalah pilihan } \\
\text { keputusan yang tepat dan terbaik. }\end{array}$ & 3.68 & Baik \\
\hline Y2.5 & $\begin{array}{l}\text { Tetap loyal apabila fasilitas dan perlengkapan yang } \\
\text { digunakanmodern dan cangih }\end{array}$ & 3.88 & Baik \\
\hline Y2.6 & $\begin{array}{l}\text { Loyal apabila saran dan masukan dari nasabah } \\
\text { dijadikan bahan pengambilan keputusan }\end{array}$ & 3.69 & Baik \\
\hline Y1.7 & $\begin{array}{l}\text { Loyal apabila bank mempertahankan demesi } \\
\text { pelayanan }\end{array}$ & 3.86 & Baik \\
\hline
\end{tabular}

Sumber: data analisis SPSS

Berdasarkan informasi pada Tabel 3 di atas dapat diketahui bahwa Loyalitas nasabah tergolong dipersepsikan baik oleh responden. Hal ini dilihat dari nilai skor rata-rata variabel kualitas layanan sebesar 3,82. Y2.1 sampai dengan Y1.7 jawaban diatas nilai rata $(3,43-4,23)$ artinya pelayanan yang diberikan oleh karyawan banco nacional timor leste sesuai dengan kinerja dan harapan sehingga nasabah akan berulang kali melakukan transaksi dan memberikan informasi kepada orang lain.

\section{Hasil Uji Asumsi Klasik}




\section{Uji Auto Korelasi}

Uji Auto Korelasi bertujuan untuk mendeteksi ada atau tidaknya korelasi antara kesalahan pengganggu pada periode $\mathrm{t}$ dan kesalahan pada periode $\mathrm{t}-1$. Berdasarkan pada judul penelitian dan pengambilan data penelitian adalah data cross section, maka pengujian asumsi autokorelasi dalam penelitian ini tidak perlu dilakukan.

\section{Uji multikolinieritas}

Hasil perhitungan didapat nilai interkorelasi dari variabel Kualitas pelayanan (X) sebesar 1.298 adalah lebih kecil dari 10 sehingga disimpulkan bahwa antar variabel bebas tidak terjadi multikolinieritas. Lihat pada Lampiran $5 b$

\section{Uji Heteroskedastisitas}

Model regresi yang baik adalah yang homoskedastisitas atau tidak terjadi heteroskedastisitas. Dari perhitungan didapat nilai koefisien korelasi antara variabel bebas dengan residu 0.243 lebih kecil dari 00.5 sehingga dapat disimpulkan bahwa tidak terjadi heteroskedastisitas. Lihat pada lampiran $5 \mathrm{~b}$

\section{Uji Normalitas}

Berdasarkan hasil perhitungan menunjukkan nilai Koefisien Kolmogorof Smirnof memiliki signifikansi yaitu 0.644 lebih besar dari 0,05 . Hal ini berarti bahwa variabel kualitas layanan, kepuasan dan loyalitas nasabah berdistribusi normal,sehingga data tersebut dapat diolah lebih lanjut untuk analisis pengujian hipotesis, lihat pada lampiran $5 \mathrm{~b}$ 


\section{Hasil Analisis Jalur}

Dalam penelitian ini digunakan analisis jalur (path analysis) untuk menguji pengaruh Kualitas layanan terhadap kepuasan dan loyalitas nasabah Berdasarkan hasil pengolahan data menggunakan program SPSS dapat diketahui hasil regresi untuk sub-struktur 1 dan sub-struktur 2, seperti disajikan pada Tabel berikut

\section{Tabel 4a Hasil Regresi Struktur 1}

\begin{tabular}{|l|c|c|c|c|}
\hline \multirow{2}{*}{ Model } & \multicolumn{2}{|c|}{$\begin{array}{c}\text { Unstandardized } \\
\text { Coefficients }\end{array}$} & $\begin{array}{c}\text { Standardized } \\
\text { Coefficients }\end{array}$ & \multirow{2}{*}{ Sig. } \\
\cline { 2 - 4 } & $\mathrm{B}$ & $\begin{array}{c}\text { Std. } \\
\text { Error }\end{array}$ & Beta & \\
\hline $1 \quad$ Constant $)$ & 0.080 & 0,080 & & 1,000 \\
\hline Kualitas Layanan & 0,081 & 0,081 & 0,470 & 0,000 \\
\hline $\mathrm{R}=0,479$ & & \\
\hline $\mathrm{R}$ Square $\left(\mathrm{R}^{2}\right)=0,230$ & & \\
\hline $\mathrm{F}=35,192 ;$ Sig. 0,000 &
\end{tabular}

a. Dependent Variable: Kepuasan Nasabah

Sumber: Data analisis SPSS

Berdasarkan tabel $4 \mathrm{a}$ hasil regresi struktur 1 diatas memberikan pengertian bahwa Nilai konstanta 0.080 mempunyai arti bahwa sebelum dipengaruhi oleh variabel depedent yaitu kepuasan nasabah bernilai positif. Dalam penelitian ini konstanta menunjukkan angka yang signifikan karena lebih besar dari 0,05, hal ini dapat diketahui bahwa sebelum dipengaruhi variable indepedent maka Kepuasan nasabah adalah tidak signifikan.

Tabel 4b Hasil Regresi Struktur 2

\begin{tabular}{|l|c|c|c|c|}
\hline \multirow{2}{*}{ Model } & \multicolumn{2}{|c|}{$\begin{array}{c}\text { Unstandardized } \\
\text { Coefficients }\end{array}$} & $\begin{array}{c}\text { Standardized } \\
\text { Coefficients }\end{array}$ & \multirow{2}{*}{ Sig. } \\
\cline { 2 - 4 } & B & $\begin{array}{c}\text { Std. } \\
\text { Error }\end{array}$ & Beta & \\
\hline $1 \quad$ Constant) & 0.000 & 0,077 & & 1,000 \\
\hline Kualitas layanan & 0,280 & 0,089 & 0,280 & 0,002 \\
\hline Kepuasan Nasabah & 0,347 & 0,089 & 0,347 & 0,000 \\
\hline
\end{tabular}




\begin{tabular}{|l|}
\hline $\mathrm{R}=0,540$ \\
\hline $\mathrm{R}$ Square $\left(\mathrm{R}^{2}\right)=0,292$ \\
\hline $\mathrm{F}=24,106 ;$ Sig. 0,000 \\
\hline
\end{tabular}

Dependent Variable: Loyalitas Nasabah

Sumber: Data Analisis SPSS

Hasil regresi struktur 2 diatas memberikan pengertian bahwa Nilai konstanta 0.080 mempunyai arti bahwa sebelum dipengaruhi oleh variabel depedent yaitu Loyalitas nasabah bernilai positif. Dalam penelitian ini konstanta menunjukkan angka yang signifikan karena lebih besar dari 0,05, hal ini dapat diketahui bahwa sebelum dipengaruhi variable indepedent maka Loyalitas Nasabah adalah tidak signifikan

\section{Hasil Pengujian Hipotesis}

Hipotesis diuji dengan t-test pada masing-masing jalur pengaruh langsung secara parsial. Hasil analisis secara ringkas analisis jalur dapat dilihat pada Tabel 5, yang menyajikan hasil pengujian hipotesis pengaruh langsung.

Tabel 5.

Hasil Pengujian Hipotesis

\begin{tabular}{|l|c|c|c|}
\hline Hubungan antar Variabel & $\begin{array}{l}\text { Koefisien } \\
\text { Jalur } \\
\text { (Standardize) }\end{array}$ & $\begin{array}{c}\text { p- } \\
\text { value }\end{array}$ & Ket. \\
\hline Kualitas pelayanan (X) $\rightarrow$ Kepuasan (Y1) & 0.470 & 0.000 & Sig. \\
\hline $\begin{array}{l}\text { Kualitas pelayanan (X) } \rightarrow \text { Loyalitas Nasabah } \\
(Y 2)\end{array}$ & 0.280 & 0.002 & Sig. \\
\hline Kepuasan P (Y1) $\rightarrow$ loyalitas Nasabah (Y2) & 0.347 & 0.000 & Sig. \\
\hline
\end{tabular}

Hasil pengujian hipotesis jalur-jalur pengaruh langsung juga dapat dilihat pada gambar diagram jalur sebagai berikut 


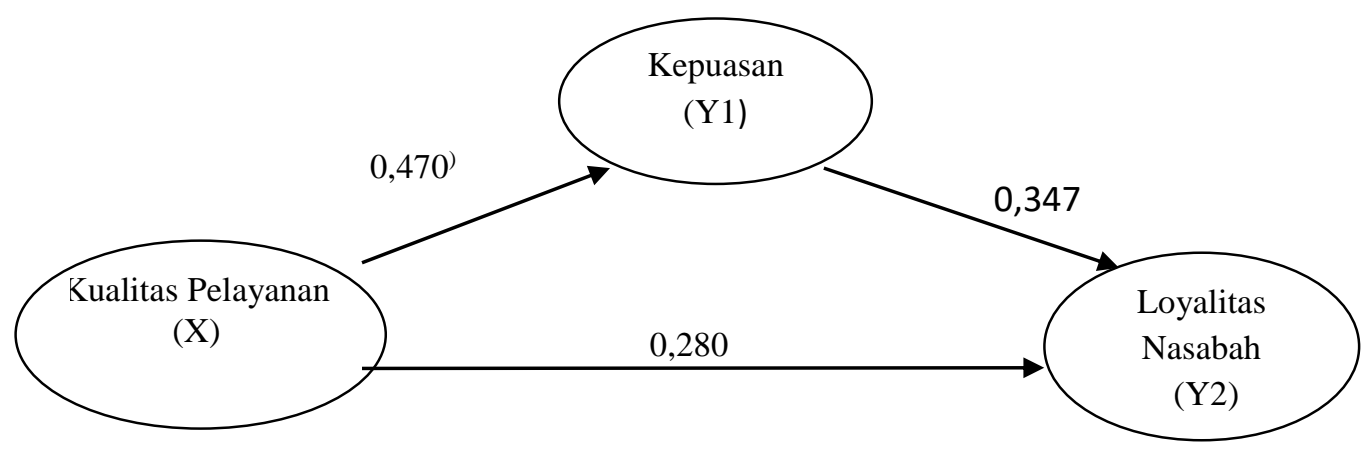

Gambar 2 Diagram Jalur Pengaruh Langsung

Berdasarkan hasil pengujian hipotesis secara statistik pada Tabel 4a dan Gambar 2 maka didapatkan sebagai berikut.

\section{Pengaruh Kualitas Pelayanan Terhadap Kepuasan Nasabah}

Hasil analisis diperoleh koefisien jalur bertanda positip sebesar 0,470 dengan $\mathrm{p}=0,000$ lebih kecil dari $\alpha(0,05)$. dari hasil tersebut dapat disimpulkan bahwa Kualitas Pelayanan berpengaruh positif dan signifikan terhadap kepuasan. Hipotesis 1 terbukti Dengan mengetahui koefisien jalur bertanda positif, maka dapat diartikan bahwa semakin baik kualitas layanan (X1) maka kepuasan (Y1) juga semakin baik atau semakin puas.

\section{Pengaruh Kualitas Pelayanan Terhadap Loyalitas Nasabah}

Hasil analisis diperoleh koefisien jalur sebesar 0,280 dengan $\mathrm{p}=0,002$ lebih kecil dari $\alpha(0,05)$, sehingga dikatakan signifikan. Dengan demikian hipotesis terbukti. Mengingat koefisien jalur bertanda positif, dapat diartikan bahwa semakin baik Kualitas Layanan (X) maka loyalitas Nasabah (Y2) juga semakin baik.

\section{Pengaruh Kepuasan terhadap Loyalitas Nasabah}


Hasil analisis diperoleh koefisien jalur sebesar 0,347 dengan $\mathrm{p}=0,000$, lebih kecil dari $\alpha(0,05)$, yang berarti signifikan. Dengan mengetahui koefisien jalur bertanda positif, dapat diartikan bahwa semakin baik atau semakin puas pelanggan maka loyalitasnya juga akan semakin baik atau semakin tinggi

\section{Uji $\mathbf{R}^{2}$}

Berdasarkan Hasil regresi sub struktur 1 dan sub struktur 2 diketahui nilai $\mathrm{R}^{2}$ masing-masing variabel endogen, yaitu: Kepuasan (Y1) diperoleh $\mathrm{R}^{2}$ sebesar 0,230, dan untuk variabel Loyalitas nasabah(Y2) diperoleh $\mathrm{R}^{2}$ sebesar 0,292. Selanjutnya maka dapat dihitung nilai predictive-relevance, dengan rumus sebagai berikut.

$$
\begin{aligned}
& R_{M}^{2}=1-\left(1-\mathrm{R}_{1}{ }^{2}\right)\left(1-\mathrm{R}_{2}{ }^{2}\right) \\
& R^{2}{ }_{M}=0,45484
\end{aligned}
$$

Dari hasil perhitungan diketahui nilai $R_{M}^{2}=0,45484$, yang menunjukkan bahwa 45,48 persen keragaman data mampu menjelaskan model Hasil ini dapat diartikan bahwa loyalitas pelanggan dijelaskan oleh Kualitas pelayanan dan kepuasan sebesar 45,48 persen dan sisanya 54,51 persen dijelaskan oleh variabel lain yang tidak dibahas dalam penelitian ini. Dengan demikian model dapat dikatakan cukup baik sehingga layak untuk memberikan penjelasan dan pengujian hipotesis.

\section{Pembahasan}

\section{Pengaruh Kualitas Pelayanan terhadap Kepuasan Nasabah}

Berdasarkan hasil penghitungan, analisis menunjukkan bahwa t hitung Kualitas Layanan (X1) dengan Kepuasan (Y1) adalah 0.470 sedangkan p-value 0.000 untuk 
jumlah sampel 120 pada taraf signifikansi $0.05 \%$ sebesar 0.470 atau t hitung > pvalue. Dengan demikian terdapat pengaruh yang positif antara Kualitas pelayanan terhadap Kepuasan. Hal tersebut dapat diartikan bahwa dimensi kualitas pelayanan berbanding lurus dengan kepuasan, yaitu semakin baik kualitas pelayanan yang diberikan maka dapat memberikan pengaruh yang positif terhadap kepuasan nasabah Banco Nacional Timor Leste, sebaliknya semakin buruk kualitas pelayanan yang diberikan maka dapat memberikan pengaruh yang negatif terhadap kepuasan nasabah Banco Nacional Comercio Timor Leste.

\section{Pengaruh Kualitas Pelayanan dan Loyalitas Nasabah}

Berdasarkan hasil penghitungan, analisis menunjukkan bahwa t hitung Kualitas Layanan (X1) Loyalitas nasabah (Y2) adalah 0.280 sedangkan p-value 0.002 untuk jumlah sampel 120 pada taraf signifikansi $0.05 \%$ sebesar 0.280 . Dengan demikian terdapat pengaruh yang positif antara Kualitas pelayanan terhadap Loyalitas nasabah. Hal tersebut dapat diartikan bahwa dimensi kualitas pelayanan berbanding lurus dengan nasabah, yaitu semakin baik kualitas pelayanan yang diberikan maka dapat memberikan pengaruh yang positif terhadap loyalitas nasabah Banco Nacional Timor Leste, sebaliknya semakin buruk kualitas pelayanan yang diberikan maka dapat memberikan pengaruh yang negatif terhadap loyalitas nasabah Banco Nacional Comercio Timor Leste.

\section{Pengaruh Kepuasan terhadap Loyalitas nasabah}

Berdasarkan hasil penghitungan, analisis menunjukkan bahwa $\mathrm{t}$ hitung kepuasan (Y1) Loyalitas nasabah (Y2) adalah 0.347 sedangkan p-value 0.000 
untuk jumlah sampel 120 pada taraf signifikansi $0.05 \%$ sebesar 347. Pengaruh yang positif dan signifikan antara kepuasan terhadap loyalitas nasabah. Hal tersebut dapat diartikan bahwa semakin tinggi kualitas pelayanan yang diberikan maka kepuasan akan semakin meninggkat sehingga nasabah bisa loyal dalam pengunan produk maupun tetap bertahan melakukan tranksasi keuangan di Banco Nacional Timor Leste.

\section{SIMPULAN DAN SARAN}

\section{Simpulan}

Kualitas Pelayanan berpengaruh dan signifikan positif hal ini mendiskripsikan bahwa semakin baik pelayanan yang diberikan oleh karyawan Banco Nacional Comercio Timor Leste dilihat dari kelima demensi maka semakin memberikan harapan dan nilai positif kepada nasabah Bank Nacional Timor Leste

Kualitas pelayanan berpengaruh positf dan signifikan terhadap loyalitas nasabah pengaruh positif hal ini mendiskripsikan bahwa pelayanan sangat meempunyai pengaruh dengan loyalitas. Hal ini, menunjukkan pelayanan sangat baik dilihat dari kelima demensi maka nasabah akan loyal dalam mengunakan produk tersebut serta tidak berpindah tempat lain untuk melakukan transaksi keuangan.

Kepuassan nasabah berpengaruh positif dan signifikan terhadap loyalitas Nasabah ada pengaruh positif, artinya apabila pelayanan yang diberikan oleh karyawan kepada pelanggan atau nasabah merasa dapat memenuhi harapan maka pelanggan pelanggan tersebut akan puas dan tetap loyal untuk melakukan transaksi keuangan pada Banco Nacional Comercio Timor Leste.

\section{Saran}


Berdasarkan pada kesimpulan yang dilakukan oleh peneliti namun perlu adanya saran dan masukan untuk melakukan perbaikan atau mempertahankan pada hasil deskripsi dari penelitian yang dilakukan oleh peneliti pada Banco Nacional Comercio Timor Leste sebagai berikut :

Kualitas pelayanan pada kelima dimensi memberikan respon yang positif namun disarankan kepada pihak lembaga keuangan Banco Nacional Timor Leste, bahwa masih terdapat hal - hal yang perlu adanya perbaikan dimensi fisik yaitu menyediakan fasilitas yang memadai serta aman bagi nasabah untuk melakukan transaksi keuangan, agar nasabah dapat memenuhi harapan dan tetap loyal menjadi nasabah bank Nacional Comercio Timor Leste.

\section{REFERENSI}

Atika Paramitha, Rahyuda, Suasana. 2013. Pengaruh Kualitas Layanan Terhadap Kepuasan dan Loyalitas Pelanggan Garuda Indobesia di Denpasar. Jurnal Fakultas Ekonomi Universitas Udayana, 7 (1): pp: 19-28.

Alida, Palilati. 2007. Pengaruh Nilai Pelanggan dan Kepuasan Terhadap Loyalitas Nasabah Tabungan Perbankan Di Sulawesi Selatan, Jurnal Manajemen dan Kewirausahaan Vol. 9 No.1

Bloemer, Josee, Ko de Ruyter and Pascal Peeters, (1998), "Investigating Drivers of Bank Loyalty: The Complex Relationship Between Image, Service, Quality and Satisfaction", International Journal of Bank Marketing,Vol.16, No.7

Felita Sasongko dan Hartono Subagio 2013. Pengaruh Kualitas Layanan Terhadap Kepuasan Pelanggan Restoran Ayam Penyet Ria Jurnal Manajemen Pemasaran Petra Vol. 1, No. 2, 1-7

Gerson, F Richard, 2001, Mengukur Kepuasan Pelanggan, Jakarta, PPM

Griffin, J. (2005). Customer loyalty menumbuhkan dan mempertahankan kesetian pelanggan. Edisi Revisi. Jakarta: Erlangga. 
Supranto J., 2006. Pengukuran Tingkat Kepuasan Pelanggan Untuk Menaikkan Pangsa Pasar, Cetakan kedua, Jakarta, Rineka Cipta.

Kotler Philip, 1997, Manajemen Pemasaran, Jakarta, Prenhallindo.

Kasmir, 2010, Pemasaran Bank, Penerbit Jakarta, Kencana.

Kotler, Philip 1997. Manajemen Pemasaran Analisis, Perencanaan, Implementasi, dan Kontrol, jilid 2, PT. Jakarta Prenhalindo.

Kotler, P., and K.L. Keller. 2012, Marketing Management, 14 th. ed. New Jersey: Pearson Education, Inc

Lovelock,Cristoper H \& Lauren K. Wright (2005) Manajemen Pemasaran Jasa Jakarta : PT.Indeks

Musriha 2009. Pengaruh Servicescape Dan Kualitas Komunikasi Karyawan Terhadap Loyalitas Nasabah Melalui Kepuasan Nasabah Bank Mandiri Di Surabaya EKUITAS ISSN 1411-0393 Akreditasi No.110/DIKTI/Kep/2009 Munawaroh. Munjiati. 2005. Analisis Pengaruh Kualitas Jasa Terhadap Kepuasan Pada Industri Pendidikan Di Yogyakarta. Jurnal Siasat Bisnis On Marketing, 2 (6): pp: 119-134.

Subarjo 2012. Pengaruh Kepuasan Terhadap Loyalitas Nasabah Kredit Pada Bukp Nanggulan Program Studi Manajemen Fakultas Ekonomi Universitas Mercu Buana Yogyakarta Jurnal Sosiohumaniora vol.3 No. 3., Mei 2012 ISSN : 2087-1899 21

Sumarwan, U. 2003. Perilaku Konsumen: Teori dan Penerapannya dalam Pemasaran: Penerbit Ghalia Indonesia, Jakarta.

Sawitri, Kerti Yasa \& Jawas 2013., Strategi Bisnis, dan Kewirausahaan, Jurnal Manajemen Vol. 7, No. 40,1

Triska, Zulkarnain \& Llilis Sulistyowati, 2014. Pengaruh Bauran Pemasaran Jasa Bank Terhadap Kepuasan Dan Implikasinya Terhadap loyalitas Debitur Bpr Di Wilayah Riau Pesisir, Jurnal Tepak Manajemen Bisnis Vol. VI No. 2 Mei

Tjiptono. Fandy. 1997. Strategi Pemasaran, Jakarta. Gramedia.

Tjiptono, Fandy. 2004. Manajemen Jasa. Yogyakarta Edisi Kedua : Penerbit Andi

Hartanto 2010. Analisis Pengaruh Kualitas Pelayanan Jasa Perbankan Terhadap Kepuasan Nasabah Study Kasus Pada Pd. Bpr Bank Program Magister Manajemen, Jogja Universitas Gunadarma 
Yesi Dewi Rahayu 2014. Presentasi Diri Customer Service Terhadap Loyalitas Nasabah, Jurnal(Online)PsikologiVol. 02 No. 02,

(http://ejournal.umm.ac.id)

Zeithaml, V.A., Berry, L.L., \& Parasuraman, A. 1996. The Behavioral Consequences of Service Quality. Journal of Marketing, -2007. Strategi Pemasaran. Edisi Pertama. Yogyakarta: Andi Ofset. Manajemen Pemasaran: Jakarta. Penerbit Airlangga 